\title{
SEGMENTASI BERBASIS K-MEANS PADA DETEKSI CITRA PENYAKIT DAUN TANAMAN JAGUNG
}

\author{
Ulla Delfana Rosiani ${ }^{1}$, Cahya Rahmad ${ }^{2}$, Marcelina Alifia Rahmawati ${ }^{3}$, Frangky Tupamahu ${ }^{4}$ \\ ${ }^{1,2,3}$ Program Studi Teknik Informatika, Jurusan Teknologi Informasi, Politeknik Negeri Malang \\ ${ }^{4}$ Teknik Informatika, Politeknik Negeri Gorontalo \\ ${ }^{1}$ rosiani@polinema.ac.id, ${ }^{2}$ cahya.rahmad@ polinema.ac.id, ${ }^{3}$ rahmarcelina9@gmail.com, \\ ${ }^{4}$ frangkytupamahu@poligon.ac.id
}

\begin{abstract}
Abstrak
Penyakit tanaman adalah kondisi dimana sel dan jaringan tanaman tidak berfungsi secara normal yang ditimbulkan karena gangguan secara terus menerus oleh agen patogen atau faktor lingkungan yang menghasilkan perkembangan gejala penyakit. Perkembangan gejala penyakit tersebut menyebabkan rendahnya produktifitas dan gagal panen bagi petani jagung. Maka dalam pengolahan citra digital dapat digunakan untuk membantu mengidentifikasi penyakit daun tanaman jagung. Pada penelitian ini, fitur yang digunakan adalah warna pada proses segmentasi dan pendekatan warna. Fitur tersebut didapatkan dari penelitian transformasi warna RGB ke CIE $L^{*} a^{*} b^{*}$, histogram a* digunakan untuk proses segmentasi berbasis $K$-Means sebagai input dengan menentukan jumlah cluster awal adalah $\mathrm{k}=3$, merandom centroid, menghitung jarak nilai pixel ke centroid, mengelompokkan nilai pixel berdasarkan jarak minimum, menghitung rata-rata cluster untuk centroid baru dan jika masih terdapat nilai pixel yang berpindah maka proses random centroid masih dilakukan hingga tidak adanya nilai pixel yang berpindah. Hasil dari citra yang telah tersegmentasi dan menggunakan pendekatan warna Euclidean Distance dapat mengidentifikasi antara penyakit hawar daun dan bercak daun. Penelitian tersebut menggunakan dataset sejumlah 30 jenis A dan B untuk training dan 10 data untuk testing telah memperoleh akurasi sebesar $90 \%$.
\end{abstract}

Kata kunci : Pengolahan Citra, Penyakit Daun Tanaman Jagung, Segmentasi Berbasis K-Means, Euclidean Distance

\section{Pendahuluan}

Penyakit tanaman adalah kondisi dimana sel dan jaringan tanaman tidak berfungsi secara normal yang ditimbulkan karena gangguan secara terus menerus oleh agen patogen atau faktor lingkungan dan akan menghasilkan perkembangan gejala. Begitu pula penyakit tanaman yang menyerang pada daun tanaman jagung, yaitu penyakit hawar daun (helminthosporium turcicum) dan penyakit bercak daun (bipolaris maydis syn).

Penyerangan penyakit tersebut menyebabkan rendahnya produktivitas dan gagal panen. Kegagalan panen selalu terjadi setiap masanya, itu bisa terjadi dikarenakan kurangnya pengetahuan petani terhadap dampak hama yang menyerang tanaman. Hal ini sangat menghawatirkan dan merugikan petani jagung.

Sedangkan, jagung merupakan sumber bahan pangan penting setelah beras di Indonesia. Selain menjadi sumber bahan pangan bagi sebagian besar peternak yang ada di Indonesia, jagung menjadi bahan pakan ternak. Pengolahan citra digital dapat digunakan untuk membantu mengidentifikasi penyakit daun tanaman jagung.
Berbagai penelitian tentang penyakit pada tumbuhan secara bioinformatika telah dilakukan. Penelitian milik Frangky Tupamahu, Septian Enggar Sukmana, Christyowidiasmoro 2015. Ekstraksi Connected Component dan Transformasi Ruang Warna CIELAB Untuk Segmentasi Citra Penyakit Pada Daun Tanaman Jagung. Berdasarkan hasil penelitian yang telah dilakukan, transformasi warna RGB ke ruang warna CIELab bersifat penting. Segmentasi objek penyakit pada citra daun berdasarkan ukuran terbesar luas area komponen objek yang terhubung pada ruang warna CIE a* dalam bentuk citra monokrom dan telah dilakukan pelabelan.

Mengidentifikasi penyakit diperlukan serangkaian proses. Segmentasi adalah salah satu metode dalam pengolahan citra digital untuk melakukan pembedaan objek pada suatu citra input. Salah satu algoritma yang bisa digunakan untuk segmentasi citra adalah K-Means. Algoritma $K$ Means berfungsi mengelompokkan citra data masukan dalam beberapa kelompok berdasarkan jarak minimum. Maka dalam penelitian yang akan dilakukan, proses segmentasi berbasis $K$-Means pada deteksi citra penyakit daun tanaman jagung. 


\section{Tinjauan Pustaka}

\subsection{Tanaman Jagung}

Jagung (Zea mays L.) merupakan salah satu tanaman pangan di Indonesia yang terpenting selain gandum dan padi. Penduduk beberapa daerah di Indonesia, misalnya di Malang, Jawa Timur juga menggunakan jagung sebagai pangan pokok setelah padi. Selain sebagai sumber karbohidrat, jagung juga ditanam sebagai pakan ternak (daun maupun tongkolnya), diambil minyaknya (dari biji), dibuat tepung (dari biji, dikenal dengan istilah tepung jagung atau maizena), dan bahan baku industri (dari tepung biji dan tepung tongkolnya).

Hal itu yang membuat petani untuk tertarik menanam jagung. Akan tetapi, penyakita tanaman jagung adalah salah satu rasa khawatir yang petani jagung rasakan. Karena tanaman jagung yang terserang penyakit dapat menimbulkan kerugian. Serangan penyakit-penyakit tanaman jagung jika tidak dikendalikan dapat menurunkan hasil produksi jagung sehingga menurunnya pendapatan petani jagung. Adapun penyakit yang menyerang tanaman jagung diantaranya:

\subsubsection{Hawar Daun}

Pada awal infeksi penyakit hawar daun pada tanaman jagung yaitu gejala berupa bercak kecil, berbentuk oval kemudian bercak semakin memanjang berbentuk ellips dan berkembang menjadi nekrotik dan disebut hawar, warnanya hijau keabu-abuan atau coklat.

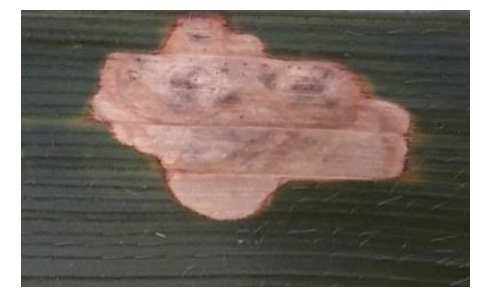

Gambar 1. Penyakit Hawar Daun

\subsubsection{Bercak Daun}

Gejala penyakit bercak daun pada tanaman jagung adalah adanya bercak berwarna coklat kemerahan yang berbentuk kumparan dan tanaman jagung yang terserang menjadi layu atau mati dalam waktu 3-4 minggu.

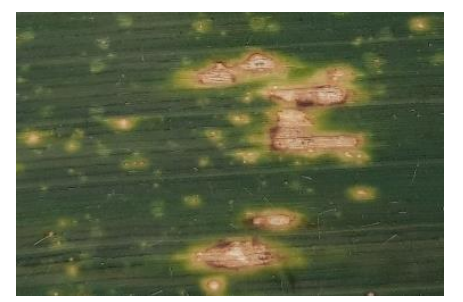

Gambar 2. Penyakit Bercak Daun

\subsection{Ruang Warna $L * a^{*} \mathbf{b}^{*}$}

Ruang Warna $L * a * b *$ yang juga dikenal dengan nama ruang nama CIELAB adalah ruang warna yang paling lengkap yang ditetapkan oleh Komisi Internasional tentang iluminasi warna (French Commision Internationale de l'eclairage, dikenal juga dengan sebutan CIE). Ruang warna $\mathrm{L} * \mathrm{a} * \mathrm{~b} *$ dirancang untuk penglihatan perkiraan manusia yang bertujuan untuk menyamakan persepsi dan komponen $\mathrm{L}$ yang sangat cocok untuk persepsi manusia. Hal ini digunakan untuk melakukan koreksi keseimbangan warna yang akurat dengan cara memodifikasi kurva output dalam komponen A dan $\mathrm{B}$, atau untuk menyesuaikan kontras ringan menggunakan komponen L. Selanjutnya ruang warna XYZ di konversi ke ruang warna $L * a * b *$ dengan persamaan:

$$
\begin{gathered}
\mathrm{L}^{*}=116 f\left(\frac{Y}{Y n}\right)-16 \\
\mathrm{a}^{*}=500\left[f\left(\frac{X}{X n}\right)-f\left(\frac{Y}{Y n}\right)\right] \\
\mathrm{b}^{*}=200\left[f\left(\frac{Y}{Y n}\right)-f\left(\frac{Z}{Z n}\right)\right]
\end{gathered}
$$

dimana $f(\mathrm{~s})=\mathrm{s}^{1 / 3}$ untuk $\mathrm{s}>0.008856$

$$
f(\mathrm{~s})=7.787 \mathrm{~s}+16 / 116 \text { untuk } \mathrm{s} \leq 0.008856
$$

\subsection{Metode K-Means}

K-Means merupakan salah satu metode data clustering non hirarki. Pengelompokan suatu data menggunakan metode $K$-Means secara umum dapat dilakukan dengan algoritme dasar yaitu:

1. Menentukan jumlah cluster awal.

2. Menempatkan centroid sesuai dengan jumlah cluster secara random.

3. Mengalokasikan data kedalam cluster sesuai dengan centroid menggunakan perhitungan jarak yang terdekat.

4. Menghitung rata-rata dari masing-masing data cluster untuk menghasilkan centroid baru.

5. Mengalokasikan data kedalam cluster sesuai dengan centroid baru menggunakan perhitungan jarak yang terdekat.

6. Kembali ke step 4, apabila masih ada data yang berpidah cluster atau terjadi perubahan nilai centroid.

Data yang digunakan untuk diklaster diperoleh dengan membandingkan jarak (distance), jarak digunakan untuk menentukan tingkat kesamaan atau ketidaksamaan dua vektor fitur.

\subsection{Euclidean Distance}

Metode Euclidean yaitu metode klasifikasi tetangga terdekatnya dengan menghitung jarak antara 
dua buah obyek, metode ini disebut juga jarak Euclidean (Pablo Navarrete and Javier Ruiz-delSolar, 2003: 6-7). Rumus perhitungan jarak ditulis sebagai berikut:

$$
d_{e}=\sqrt{\sum_{k=1}^{m}\left(f d_{i, k}-k_{j}\right)^{2}}
$$

\section{Metodologi}

Dalam metode penelitian ini akan menjelaskan langkah-langkah yang dilakukan untuk merancang sistem adalah sebagai berikut:

\subsection{Metode Pengumpulan Data}

Metode pengumpulan data dalam penelitian ini adalah data image daun tanaman jagung yang berpenyakit hawar daun dan bercak daun. Pengumpulan data secara langsung dilakukan di kebun jagung Kelurahan Tlogowaru, Kecamatan Kedungkandang, Malang.

Data pendukung yang berasal dari narasumber dan pakar yaitu instansi yang terkait Dinas Pertanian Dan Ketahanan Pangan Kota Malang bersama Bapak M. Ainun Mustofa selaku Seksi Pengendalian Dan Penanggulangan Bencana Pertanian yang mengarahkan penulis untuk berkonsultasi bersama Bapak H. Moh. Nawi selaku Pengamat Hama Penyakit (PHP) Dinas Pertanian Jawa Timur. Berikut cara pengambilan data:

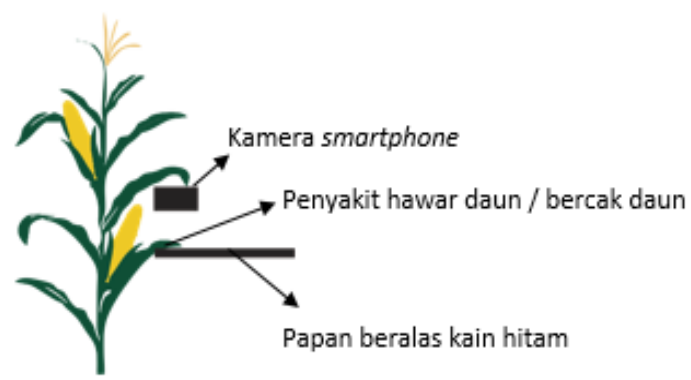

Gambar 3. Cara Pengambilan Data

Cara pengumpulan data secara langsung pada daun tanaman jagung yang ada di kebon jagung, dengan cara papan diberi kain hitam diletakkan dibawah daun penyakit jagung lalu melakukan pengambilan citra dengan kamera smartphone pada daun penyakit jagung tersebut dengan jarak ambil menyesuaikan penyakit $10 \mathrm{~cm}-20 \mathrm{~cm}$, pengambilan dilakukan pada jam 06:00-08:00 rekomendasi jam tersebut dari peneliti sebelumnya yaitu Bapak Frangky Tupamahu dengan pencahayaan yang cukup.

\subsection{Metode Pengolahan Data}

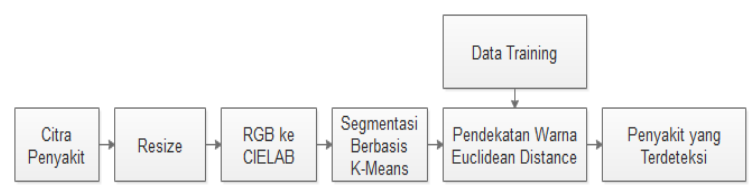

Gambar 4. Metode Pengolahan Data

Metode pengolahan data yang digunakan untuk implementasi sistem deteksi penyakit daun tanaman jagung ini dengan fitur yang digunakan adalah data warna pada proses segmentasi yang berupa nili pixel. Citra penyakit sebagai masukkan yang selanjutnya akan dilakukan pengubahan ukuran citra masukkan tersebut. Setelah proses pengubahan ukuran citra lalu proses transformasi warna RGB ke CIELAB dimana hasil tersebut berupa nilai pixel yang digunakan sebagai masukkan pada proses segmentasi berbasis $K$-Means. Hasil dari proses segmentasi tersebut yang diinputkan ke dalam sistem akan dijadikan data training yang nantinya akan menghasilkan nilai pixel yang akan digunakan dalam pendekatan warna Euclidean Distance.

\subsection{Metode Pengujian}

Tahap ini adalah tahap penyatuan unit-unit program dan kemudian akan dilakukan pengujian secara keseluruhan pada aplikasi tersebut. Proses pengujian dilakukan dalam beberapa tahap yaitu:

a. Memilih citra masukan yang telah disediakan yaitu citra penyakit daun tanaman jagung (penyakit hawar daun atau bercak daun).

b. Mengubah ukuran citra masukan menjadi 400x400.

c. Melakukan transformasi warna dari RGB ke CIE $L * a * b *$.

d. Melakukan split warna CIE $L^{*} a * b *$ dan histogram $a^{*}$ yang nantinya akan digunakan sebagai masukkan dalam proses berikutnya yaitu proses segmentasi.

e. Melakukan proses segmentasi menggunakan metode K-Means.

f. Menghitung jarak kemiripan warna dari hasil segmentasi yang disimpan pada training dengan menggunakan pendekatan warna Euclidean Distance.

\section{Perancangan}

\subsection{Deskripsi Sistem}

Penjelasan flowchart sistem yaitu dimulai dengan input citra daun penyakit tanaman jagung (hawar daun atau bercak daun) kemudian memasuki resize (mengubah ukuran besarnya citra kedalam pixel) citra inputan menjadi 400x400. Berikutnya adalah transformasi warna pada citra yaitu dari RGB ke CIE $L * a * b *$. Split CIE $L * a * b *$ dan histogram a*. 
Lalu, segmentasi menggunakan metode K-Means. Selanjutnya pendekatan warna menggunakan Euclidean Distance yang mendeteksi penyakit daun tanaman jagung yaitu antara penyakit hawar daun dan bercak daun.

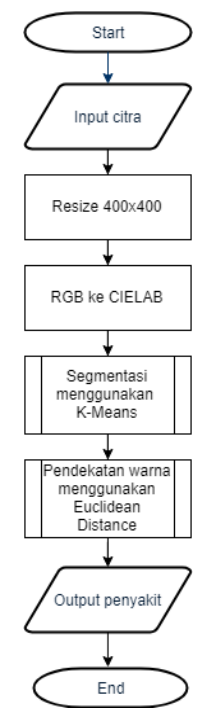

Gambar 5. Flowchat Sistem

\subsection{Analisis Sistem}

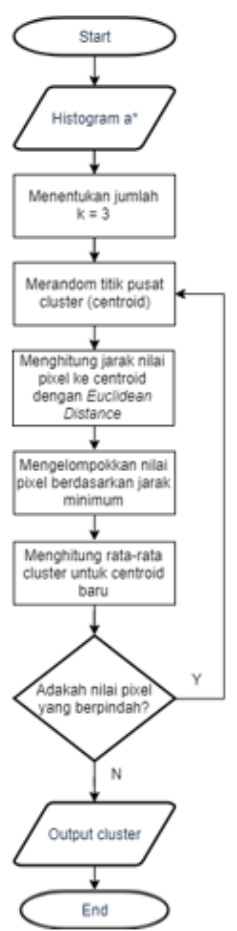

Gambar 6. Flowchat Segmentasi Berbasis K-Means

Penjelasan flowchart segmentasi berbasis $K$ Means yaitu dengan cara inputan menggunakan histogram a* digunakan untuk proses segmentasi berbasis $K$-Means sebagai input dengan menentukan jumlah cluster awal adalah $\mathrm{k}=3$, merandom centroid, menghitung jarak nilai pixel ke centroid, mengelompokkan nilai pixel berdasarkan jarak minimum, menghitung rata-rata cluster untuk centroid baru dan jika masih terdapat nilai pixel yang berpindah maka proses random centroid masih dilakukan hingga tidak adanya nilai pixel yang berpindah.

\section{Implementasi}

Implementasi adalah penulisan bahasa pemograman pada komputer, agar kode program dapat berjalan sesuai dengan rancangan. Berikut langkah langkah pada tahap implementasi.

\subsection{Instalasi}

Instalasi dimulai dengan mempersiapkan tools yang diperlukan yaitu python interpreter beserta library yang dibutuhkan. Selanjutnya memasang database sqlite3 yang digunakan sebagai penyimpanan data. Pada bagian tampilan, yang perlu dikonfigurasi adalah Django.

\subsection{Menulis Program}

Proses implementasi selanjutnya yaitu menulis kode program yang digunakan untuk perhitungan metode-metode yang diperlukan. Proses ini ditulis menggunakan bahasa python.

\subsection{Membuat Antarmuka}

Proses yang terakhir yaitu membuat tampilan website yang akan diakses oleh user dan terintegrasi dengan kode program yang ditulis menggunakan bahasa python.

\section{Pengujian}

Melakukan pengujian pada sistem yang telah dibuat berarti melakukan pengecekan apakah sistem yang dibuat sudah sesuai dengan tujuan yang telah ditetapkan.

\subsection{Pengujian Fungsional}

Pengujian fungsional yang dimaksudkan untuk melihat apakah sistem sudah berjalan dengan tepat mulai dari proses input gambar, penyimpanan gambar, ekstraksi fitur, penyimpanan data fitur ke dalam database serta proses perhitungan klasifikasi dapat berjalan tanpa muncul error, sebagai berikut:

Tabel 1. Hasil Pengujian Fungsional

\begin{tabular}{|l|l|l|c|}
\hline No & Pegujian & \multicolumn{1}{|c|}{$\begin{array}{l}\text { Hasil yang } \\
\text { diharapkan }\end{array}$} & Hasil \\
\hline 1 & $\begin{array}{l}\text { Button } \\
\text { training }\end{array}$ & $\begin{array}{l}\text { Dapat menuju } \\
\text { halaman training }\end{array}$ & Berhasil \\
\hline 2 & $\begin{array}{l}\text { Button } \\
\text { testing }\end{array}$ & $\begin{array}{l}\text { Dapat menuju } \\
\text { halaman testing }\end{array}$ & Berhasil \\
\hline
\end{tabular}




\begin{tabular}{|c|c|c|c|}
\hline No & Pegujian & $\begin{array}{c}\text { Hasil yang } \\
\text { diharapkan }\end{array}$ & Hasil \\
\hline 3 & $\begin{array}{l}\text { Input } \\
\text { citra } \\
\text { training }\end{array}$ & $\begin{array}{l}\text { Citra dapat } \\
\text { ditampilkan dengan } \\
\text { hasil citra rgb, } \\
L^{*} a^{*} b^{*}, \quad \text { split } L, \\
\text { split } a^{*} \text {, split } b^{*}, \mathrm{k} 1, \\
\mathrm{k} 2, \mathrm{k} 3\end{array}$ & Berhasil \\
\hline 4 & $\begin{array}{l}\text { Label } \\
\text { penyakit }\end{array}$ & $\begin{array}{l}\text { Pelabelan yang } \\
\text { ditraining bersama } \\
\text { inputan citra dapat } \\
\text { insert database }\end{array}$ & Berhasil \\
\hline 5 & $\begin{array}{l}\text { Simpan } \\
\text { training }\end{array}$ & $\begin{array}{l}\text { Parameter mean } r, \\
\text { mean } g, \text { mean } b \text {, } \\
\text { mean } a^{*} \text { disimpan } \\
\text { pada database }\end{array}$ & Berhasil \\
\hline 6 & $\begin{array}{l}\text { Input } \\
\text { citra } \\
\text { testing }\end{array}$ & 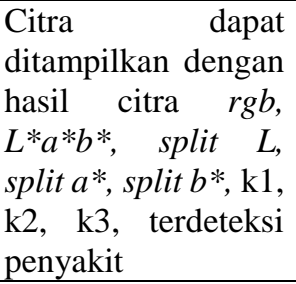 & Berhasil \\
\hline 7 & $\begin{array}{l}\text { Proses } \\
\text { testing }\end{array}$ & $\begin{array}{lr}\text { Dapat terdeteksi } \\
\text { penyakit } \\
\text { inputan citra }\end{array}$ & Berhasil \\
\hline
\end{tabular}

\subsection{Analisa Hasil Penelitian}

Dari hasil identifikasi terbaik yang dilakukan tentang keakuratan sistem didapatkan tingkat keberhasilan sistem deteksi penyakit daun tanaman jagung dengan segmentasi berbasis $K$-Means, sebagai berikut:

Tabel 2. Hasil Pengujian

\begin{tabular}{|c|c|c|c|}
\hline No & $\begin{array}{c}\text { Citra Daun } \\
\text { Penyakit }\end{array}$ & $\begin{array}{c}\text { Hasil } \\
\text { Aplikasi }\end{array}$ & Harapan \\
\hline 1 & & $\begin{array}{l}\text { Hawar } \\
\text { Daun }\end{array}$ & $\begin{array}{c}\text { Hawar } \\
\text { Daun }\end{array}$ \\
\hline 2 & & $\begin{array}{l}\text { Hawar } \\
\text { Daun }\end{array}$ & $\begin{array}{c}\text { Hawar } \\
\text { Daun }\end{array}$ \\
\hline 3 & & $\begin{array}{l}\text { Hawar } \\
\text { Daun }\end{array}$ & $\begin{array}{c}\text { Hawar } \\
\text { Daun }\end{array}$ \\
\hline
\end{tabular}

\begin{tabular}{|c|c|c|c|}
\hline No & $\begin{array}{c}\text { Citra Daun } \\
\text { Penyakit }\end{array}$ & $\begin{array}{c}\text { Hasil } \\
\text { Aplikasi } \\
\end{array}$ & Harapan \\
\hline 4 & & $\begin{array}{c}\text { Bercak } \\
\text { Daun }\end{array}$ & $\begin{array}{l}\text { Hawar } \\
\text { Daun }\end{array}$ \\
\hline 5 & & $\begin{array}{l}\text { Hawar } \\
\text { Daun }\end{array}$ & $\begin{array}{c}\text { Hawar } \\
\text { Daun }\end{array}$ \\
\hline 6 & & $\begin{array}{c}\text { Bercak } \\
\text { Daun }\end{array}$ & $\begin{array}{c}\text { Bercak } \\
\text { Daun }\end{array}$ \\
\hline 7 & & $\begin{array}{c}\text { Bercak } \\
\text { Daun }\end{array}$ & $\begin{array}{l}\text { Bercak } \\
\text { Daun }\end{array}$ \\
\hline 8 & & $\begin{array}{c}\text { Bercak } \\
\text { Daun }\end{array}$ & $\begin{array}{c}\text { Bercak } \\
\text { Daun }\end{array}$ \\
\hline 9 & & $\begin{array}{c}\text { Bercak } \\
\text { Daun }\end{array}$ & $\begin{array}{c}\text { Bercak } \\
\text { Daun }\end{array}$ \\
\hline 10 & & $\begin{array}{c}\text { Bercak } \\
\text { Daun }\end{array}$ & $\begin{array}{l}\text { Bercak } \\
\text { Daun }\end{array}$ \\
\hline
\end{tabular}

Dari keseluruhan data yaitu 10 data penyakit daun tanaman jagung (hawar daun dan bercak daun) hasil pengujian, maka didapatkan tingkat akurasi sebagai berikut:

Presentase Keakuratan $=\frac{\text { Sesuai }}{\text { JumlahSampel }} \times 100 \%$

Presentase Keakuratan $=\frac{9}{10} \times 100 \%=90 \%$ 


\section{Kesimpulan dan Saran}

\subsection{Kesimpulan}

Berdasarkan hasil dari penelitian yang sudah dilakukan, maka dapat ditarik kesimpulan sebagai berikut:

1. Metode penelitian data dilakukan dengan validasi pihak narasumber dan pakar.

2. Dalam membangun sistem deteksi penyakit daun tanaman jagung yaitu hawar daun dan bercak daun berdasarkan warna dengan segmentasi berbasis $K$-Means dan pendekatan warna dengan Euclidean Distance dipengaruhi beberapa faktor yaitu posisi daun, cahaya serta background saat pengambilan citra.

3. Sistem yang dibuat dapat mendeteksi penyakit hawar daun atau bercak daun dengan segmentasi $K$-Means dan pendekatan warna dengan Euclidean Distance.

4. Hasil pengujian deteksi citra penyakit daun tanaman jagung yaitu hawar daun dan bercak daun yang telah dilakukan mendapatkan presentase pengujian sistem sebesar $90 \%$.

\subsection{Saran}

Penelitian ini masih jauh dari kata sempurna, oleh karena itu berikut ini beberapa saran untuk pengembangan penelitian selanjutnya:

1. Melakukan penelitian dataset dengan ketetapan yang sama seperti jarak, posisi daun, dan cahaya.

2. Melakukan penelitian dengan menggunakan cropping pada area penyakit.

3. Perlu dilakukan ekstraksi fitur yang berbeda yang dapat membedakan bentuk dari hawar daun dan bercak daun selain dari tekstur warna.

4. Perlu dikembangkan sistem berbasis android.

\section{Daftar Pustaka}

Semangun, H. (2004). Penyakit-penyakit Tanaman Pangan di Indonesia. Yogyakarta: Gajah Mada University Press.

Hadianti, S., Riana, D. (2018). Segmentasi Citra Bemisia Tabaci Menggunakan Metode KMeans. Jakarta: Seminar Nasional Inovasi dan Tren (SNIT).

Latifahani, N., Cholil, A., Djauhari, S. (2014). Ketahanan Beberapa Varietas Jagung (Zea Mays L.) Terhadap Serangan Penyakit Hawar Daun. Malang: Jurnal HPT Vol 2. No. 1 Pebruari. ISSN : $2338-4336$.

Tupamahu, F., Sukmana, S. E., Christyowidiasmoro. (2015). Ekstraksi Connected Component dan Transformasi Ruang Warna CIELAB Untuk Segmentasi Citra Penyakit Pada Daun Tanaman Jagung. Surabaya: Seminar Nasional ke-9: Rekayasa Teknologi Industri dan Informasi.

Febrinanto, F. G., Dewi, C., Wiratno, A. T. (2018). Implementasi Algoritme K-Means Sebagai Metode Segmentasi Citra Dalam Identifikasi Penyakit Daun Jeruk. Malang: Jurnal Pengembangan Teknologi Informasi dan Ilmu Komputer Vol 2. No. 11 November. . EISSN: 2548-964X.

Atina. (2017). Segmentasi Citra Paru Menggunakan Metode K-Means Clustering. Jurnal Pendidikan Fisika dan Keilmuan (JPFK) Vol 3. No. 2 September. ISSN: 2442-904x.

Agusta, Y. (2007). K-Means - Penerapan, Permasalahan dan Metode Terkait. Jurnal Sistem dan Informatika Vol 3. pp. 47-60.

Rulaningtyas, R., Suksmono, A. B., Mengko, T. L. R. \& Saptawati, G. A. P. (2015). Segmentasi Citra Berwarna dengan Menggunakan Metode Clustering Berbasis Patch untuk Identifikasi Mycobacterium Tuberculosis. Biosains, 17.

Wulanningrum, R., Rachmad, A. (2012). Pengenalan Rumput Laut Menggunakan Euclidean Distance Berbasis Ekstraksi Fitur. Yogyakarta: Seminar Nasional Aplikasi Teknologi Informasi 2012 (SNATI 2012) ISSN: 1907-5022.

Prabiantissa, C. N., Tri, A. R., Asmara, R. A. (2017). Sistem Identifikasi Batik Alami Dan Batik Sintetis Berdasarkan Karakteristik Warna Citra Dengan Metode K-Means Clustering. Malang: Politeknik Negeri Malang. 